\title{
Isolasi dan Identifikasi Endomikoriza pada Perakaran Tanaman Jagung (Zea mays L.) Dataran Sedang serta Perbanyakannya pada Tingkat Kadar Air Tanah Berbeda
}

\author{
NGAKAN MADE ADI WEDAGAMA, I MADE SUKEWIJAYA*), \\ NI LUH KARTINI, DAN I NYOMAN RAI
}

Program Studi Agroekoteknologi, Fakultas Pertanian, Universitas Udayana

Jl. P.B. Sudirman Denpasar Bali 80232

${ }^{*}$ E-mail: madesukewijaya@unud.ac.id

\begin{abstract}
Isolation and Identification of Endomycorrhizal on Corn Root (Zea mays L.) at Medium Plain and its Propagation at Different Soil Water Level. Endomycorrhizal has several benefits that can increase the absorption of water and nutrients, protect plants from root pathogens and toxic elements, play a role in the improvement of soil structure, and increase the solubility of nutrients. The purpose of this research is to find out the types endomycorrhizal contained in the corn roots at medium plains in Gianyar Regency, and the influence of different soil water level to endomycorrhizal ability to reproduce spores. This research was conducted from September 2017 to February 2018. The method of the research includes exploration, isolation, identification, propagation of spores endomycorrhizal, and soil samples analysis. Isolation and identification result found 2 genus of spores endomycorrhizal that was Glomus and Acaulospora, with various spore amount and the level of infection endomycorrhizal was very high with percentage of $83.33-86.67 \%$. Spores propagation test results showed that the highest percentage enhacement of spores endomycorrhizal amount was found in the third soil sampling location in soil water level of $40 \%$ field capacity treatment with percentage of $551.85 \%$. The level of endomycorrhizal infections at the roots of all treatment of soil sampling location and soil water level were very high with percentage of $100 \%$.
\end{abstract}

Keywords: endomycorrhizal, location of the soil sampling, soil water level

\section{PENDAHULUAN}

Pertumbuhan dan produksi tanaman dipengaruhi oleh dua faktor yaitu faktor internal dan faktor eskternal. Faktor internal merupakan faktor yang berasal dari tanaman itu sendiri (faktor genetik), sedangkan faktor eksternal merupakan faktor yang berasal dari luar tanaman (faktor lingkungan). Jumin (2012) menyatakan bahwa aktivitas fisiologis tanaman akan terganggu apabila terjadi kekurangan air, sehingga dapat mengakibatkan terhambatnya proses 
NGAKAN MADE ADI WEDAGAMA. et al. Isolasi dan Identifikasi Endomikoriza pada Perakaran...

pertumbuhan, bahkan dapat menyebabkan kematian pada tanaman apabila kekurangan air terjadi secara terus-menerus. Upaya peningkatan produksi tanaman yang sering dilakukan petani adalah dengan melakukan pemupukan yaitu dengan menggunakan pupuk anorganik. Menurut Supartha et al. (2012), penggunaan pupuk anorganik yang relatif tinggi secara terus-menerus dapat menyebabkan terjadinya penurunan produktivitas lahan pertanian serta menyebabkan dampak negatif terhadap lingkungan. Endomikoriza dapat digunakan sebagai pupuk hayati atau sebagai alternatif untuk menghindari terjadinya kerusakan tanah akibat penggunaan pupuk anorganik (Sundari et al., 2011). Chairuman (2008) menyatakan bahwa dengan adanya simbiosis dengan endomikoriza tanaman inang memperoleh banyak manfaat untuk pertumbuhannya, baik secara langsung yaitu dengan meningkatkan penyerapan air, unsur hara, dan melindungi tanaman dari patogen akar, serta unsur toksik, maupun secara tidak langsung yaitu endomikoriza berperan dalam perbaikan struktur tanah dan meningkatkan kelarutan unsur hara.

Penelitian ini bertujuan untuk mengetahui genus endomikoriza yang ditemukan pada perakaran tanaman jagung dataran sedang, karakter morfologi spora dari berbagai genus endomikoriza pada perakaran tanaman jagung dataran sedang, tingkat infeksi endomikoriza pada perakaran tanaman jagung dataran sedang, dan pengaruh tingkat kadar air tanah yang berbeda terhadap tingkat infeksi dan persentase peningkatan jumlah spora endomikoriza.

\section{BAHAN DAN METODE}

Penelitian ini dilaksanakan di daerah dataran sedang Kabupaten Gianyar (ketinggian 200-500 $\mathrm{m}$ di atas permukaan laut), Laboratorium Sumberdaya Genetik dan Biologi Molekuler Universitas Udayana, Laboratorium Agronomi dan Hortikultura, Fakultas Pertanian Universitas Udayana, Laboratorium Kimia dan Kesuburan Tanah, Fakultas Pertanian Universitas Udayana dari bulan September 2017 sampai dengan Februari 2018.

Alat-alat yang digunakan dalam penelitian ini adalah cangkul, cetok, gunting, tissue, hand sprayer, cool box, kantong plastik, kertas label, pinset, cawan petri, oven, object glass, cover glass, mikroskop stereo, mikroskop compound, timbangan, gelas beaker, sendok, tabung sentrifus, mesin sentrifus, botol semprot, autoklaf, pipet mikro, pipet tetes, alat hitung (hand counter), jarum oose, pot, alat tulis, kamera, serta satu 
set saringan dengan diameter lubang $1 \mathrm{~mm}$, $500 \mu \mathrm{m}, 212 \mu \mathrm{m}, 106 \mu \mathrm{m}$, dan $53 \mu \mathrm{m}$. Bahan-bahan yang digunakan dalam penelitian ini adalah akar tanaman jagung, tanah sampel, air, glukosa $60 \%, \mathrm{KOH} 10 \%$, $\mathrm{H}_{2} \mathrm{O}_{2} 3 \%, \mathrm{HCl} 1 \%$, lactoglyserol, trypan blue, bibit jagung ketan (varietas Arumba), zeolit, pasir kuarsa, dan larutan Melzer.

Pelaksanaan penelitian meliputi eksplorasi, isolasi, identifikasi, perbanyakan spora, dan analisis sampel tanah. Eksplorasi dilaksanakan dengan mengambil sampel tanah dan akar dari perakaran tanaman jagung pada dataran sedang (ketinggian 200$500 \mathrm{~m}$ di atas permukaan laut) di Kabupaten Gianyar. Isolasi spora dilakukan dengan menggunakan metode tuang saring dari Pacioni (1992) dalam Pangaribuan (2014) dan dilanjutkan dengan teknik sentrifus dari Brundrett et al. (1996) yang dimodifikasi. Tahapan identifikasi dilakukan dengan mencocokkan bentuk spora, warna spora, dan ukuran diameter spora berdasarkan pedoman INVAM (2017), dan reaksi spora ketika ditetesi dengan larutan Melzer. Perbanyakan spora endomikoriza dilakukan dengan menggunakan metode Wirawan et al. (2015) yang dimodifikasi. Perbanyakan spora endomikoriza menggunakan rancangan acak lengkap (RAL) pola faktorial. Faktor pertama adalah lokasi pengambilan sampel tanah (L) yang terdiri atas 3 taraf, yaitu $\mathrm{L}_{1}=$ lokasi pengambilan sampel tanah pertama (lahan penanaman jagung yang sebelumnya ditanaman tanaman jahe), $\mathrm{L}_{2}=$ lokasi pengambilan sampel tanah kedua (lahan penanaman jagung yang sebelumnya ditanaman tanaman padi), $\mathrm{L}_{3}=$ lokasi pengambilan sampel tanah ketiga (lahan penanaman jagung yang sebelumnya ditanami tanaman kedelai), dan faktor kedua adalah kadar air tanah (A) yang terdiri atas 3 taraf, yaitu $\mathrm{A}_{1}=100 \%$ kapasitas lapang, $\mathrm{A}_{2}=$ $70 \%$ kapasitas lapang, $\mathrm{A}_{3}=40 \%$ kapasitas lapang. Kombinasi perlakuan yang diperoleh yaitu 9 kombinasi perlakuan, masing-masing perlakuan diulang 3 kali sehingga diperoleh 27 unit percobaan. Analisis tanah yang dilakukan adalah analisis $\mathrm{pH}$ tanah, $\mathrm{P}$ tersedia, $\mathrm{C}$ organik, dan tekstur tanah.

Variabel yang diamati pada penelitian ini adalah a) jenis-jenis dan karakter morfologi spora endomikoriza (sebelum dan setelah perbanyakan), b) jumlah spora endomikoriza (sebelum dan setelah perbanyakan), c) persentase peningkatan jumlah spora endomikoriza setelah perbanyakan, d) tingkat infeksi endomikoriza pada akar (sebelum dan setelah perbanyakan), e) jumlah daun, f) tinggi tanaman, g) diameter batang tanaman, h) 
NGAKAN MADE ADI WEDAGAMA. et al. Isolasi dan Identifikasi Endomikoriza pada Perakaran...

berat basah total tanaman, dan i) berat kering oven total tanaman.

Data hasil isolasi dan identifikasi ditabulasi dan dianalisis secara deskriptif, sedangkan data hasil perbanyakan spora pada kadar air tanah berbeda, jumlah daun, tinggi tanaman, diameter batang tanaman, berat basah total tanaman, dan berat kering oven total tanaman dianalisis dengan menggunakan analisis sidik ragam, apabila terdapat pengaruh nyata, maka dilanjutkan dengan uji jarak berganda Duncan.

\section{HASIL DAN PEMBAHASAN}

Berdasarkan hasil isolasi dan identifikasi endomikoriza pada perakaran tanaman jagung di dataran sedang Kabupaten Gianyar ditemukan 2 genus spora endomikoriza yaitu Glomus dan Acaulospora (Tabel 2). Tabel 2 juga menunjukkan bahwa spora dari genus Glomus lebih mendominasi pada tiga lokasi pengambilan sampel tanah tersebut. Hal ini dapat disebabkan karena Glomus mempunyai tingkat adaptasi yang cukup tinggi terhadap lingkungan (Cahyani et al., 2014). Selanjutnya dinyatakan bahwa Glomus dapat berkembang dengan baik pada tanah yang mempunyai tekstur liat berpasir, lempung berliat, lempung, dan lempung berpasir.

Jumlah spora endomikoriza yang ditemukan pada sampel tanah kedua lebih rendah dibandingkan dengan jumlah spora endomikoriza pada sampel tanah pertama dan ketiga (Tabel 2), hal ini dapat disebabkan karena sampel tanah kedua mempunyai kandungan $\mathrm{P}$ tersedia yang tinggi (Tabel 1). Nurhandayani et al. (2013) menyatakan bahwa jumlah spora endomikoriza menurun pada tanah yang mempunyai kandungan $\mathrm{P}$ tinggi karena berkurangnya eksudat akar yang dihasilkan oleh tanaman.

Tingkat infeksi endomikoriza pada perakaran tanaman jagung yang ditemukan tergolong sangat tinggi dengan persentase 83,33-86,67\% (Tabel 2). Hal ini dapat disebabkan karena tanaman jagung merupakan tanaman yang ideal untuk perkembangan hifa dan perbanyakan endomikoriza, tanaman jagung mempunyai sistem perakaran yang banyak dan halus, dan mikroorganisme mudah berkembang di perakaran tersebut termasuk endomikoriza (Wirawan et al., 2015). 
Tabel 1. Hasil Analisis Tanah

\begin{tabular}{ccccc}
\hline $\begin{array}{c}\text { Lokasi pengambilan } \\
\text { sampel tanah }\end{array}$ & $\mathrm{pH}$ & C organik (\%) & P tersedia (ppm) & Tekstur \\
\hline $\mathrm{L}_{1}$ & $5,7(\mathrm{AM})$ & $2,73(\mathrm{~S})$ & $20,95(\mathrm{~S})$ & Lempung berliat \\
$\mathrm{L}_{2}$ & $6,3(\mathrm{AM})$ & $2,73(\mathrm{~S})$ & $31,54(\mathrm{~T})$ & Lempung \\
$\mathrm{L}_{3}$ & $6,0(\mathrm{AM})$ & $2,34(\mathrm{~S})$ & $18,56(\mathrm{~S})$ & Lempung berliat \\
\hline
\end{tabular}

Keterangan : $\mathrm{AM}=$ agak masam

$$
\begin{aligned}
& \mathrm{S}=\text { sedang } \\
& \mathrm{T}=\text { tinggi }
\end{aligned}
$$

Tabel 2.Persentase Infeksi Endomikoriza pada Akar, Jumlah Spora Endomikoriza dan Genus Spora Endomikoriza yang Ditemukan

\begin{tabular}{cccc}
\hline $\begin{array}{c}\text { Lokasi pengambilan } \\
\text { sampel tanah }\end{array}$ & $\begin{array}{c}\text { Persentase infeksi } \\
\text { endomikoriza pada } \\
\text { akar (\%) }\end{array}$ & $\begin{array}{c}\text { Jumlah spora } \\
\text { endomikoriza (per 100 } \\
\text { g tanah sampel) }\end{array}$ & $\begin{array}{c}\text { Genus spora endomikoriza yang } \\
\text { ditemukan }\end{array}$ \\
\hline $\mathrm{L}_{1}$ & 86,67 & 51 & Glomus, Acaulospora \\
$\mathrm{L}_{2}$ & 83,33 & 40 & Glomus \\
$\mathrm{L}_{3}$ & 83,33 & 45 & Glomus, Acaulospora \\
\hline
\end{tabular}

Karakter morfologi spora endomikoriza dari genus Glomus yang ditemukan mempunyai bentuk spora bulat, berwarna kuning dan coklat, diameter spora berukuran 60-117 $\mu \mathrm{m}$, dan terdapat dudukan hifa, sedangkan karakter morfologi spora endomikoriza dari genus Acaulospora yang ditemukan mempunyai bentuk spora bulat, berwarna jingga dan cokelat, diameter spora berukuran 65-103 $\mu \mathrm{m}$, dan terdapat ornamen (Gambar 1). Karakter morfologi spora dari genus Glomus dan Acaulospora yang ditemukan mempunyai kemiripan dengan karakter morfologi spora dari dari genus Glomus dan Acaulospora pada INVAM (2017). Suamba et al. (2014) menyatakan bahwa masing-masing genus endomikoriza mempunyai karakteristik spora yang khas, yaitu pada genus Glomus terdapat dudukan hifa, sedangkan pada genus Acaulospora terdapat ornamen. Spora endomikoriza dari genus Glomus yang ditemukan tidak bereaksi ketika ditetesi dengan larutan Melzer, sedangkan spora Acaulospora bereaksi ketika ditetesi larutan Melzer.

Berdasarkan hasil pewarnaan (staining) akar tanaman jagung ditemukan struktur infeksi endomikoriza yaitu vesikula dan hifa (Gambar 2), namun pada penelitian ini tidak ditemukan struktur infeksi berupa arbuskula. Hal ini dapat disebabkan karena struktur arbuskula telah mengalami lisis (Smith dan Smith, 1995 dalam Raharja, 2015). 
NGAKAN MADE ADI WEDAGAMA. et al. Isolasi dan Identifikasi Endomikoriza pada Perakaran...
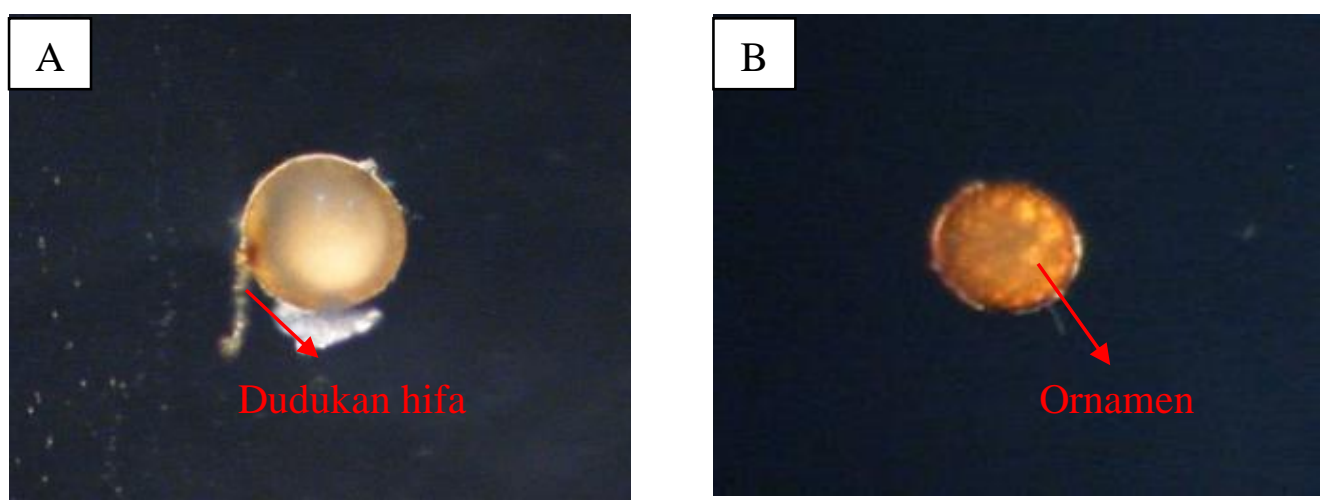

Gambar 1. Spora Endomikoriza dengan Genus Glomus (A) dan Acaulospora (B) dengan Pembesaran $100 \mathrm{X}$
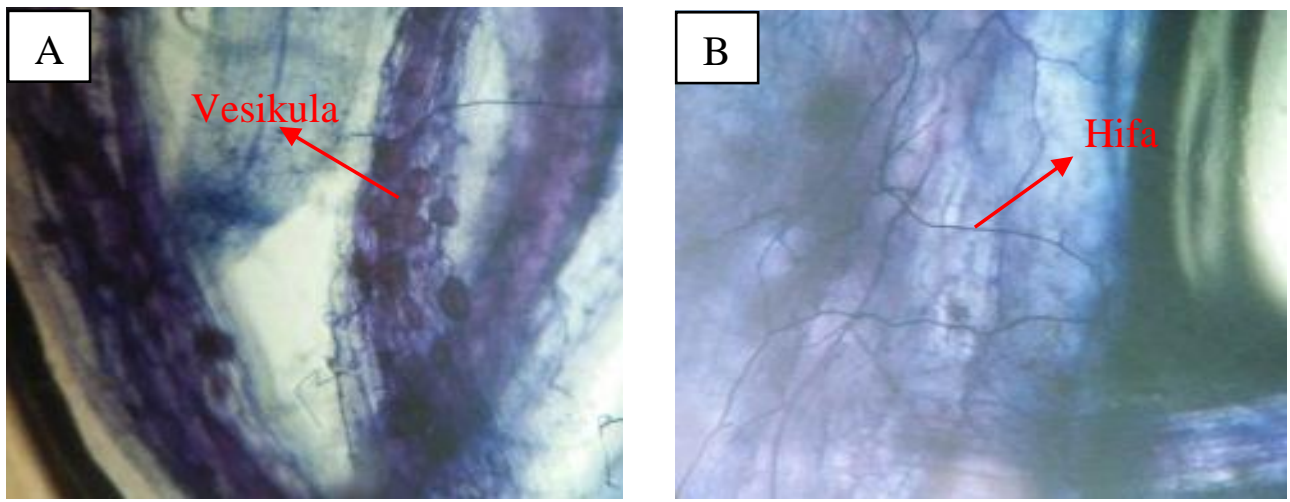

Gambar 2. Struktur Infeksi Endomikoriza Berupa Vesikula (A) dan Hifa (B) pada Akar dengan Pembesaran $100 \mathrm{X}$

Persentase peningkatan spora Pembentukan spora meningkat pada kondisi endomikoriza tertinggi terdapat pada kering, karena kondisi kering merangsang perlakuan lokasi pengambilan sampel tanah pembentukan spora, sehingga jumlah spora ketiga dengan kadar air tanah 40\% kapasitas yang terbentuk lebih banyak dan merupakan lapang $\left(\mathrm{L}_{3} \mathrm{~A}_{3}\right)$ yaitu $551,85 \%$ (Tabel 3). Hasil bentuk respon alami dari endomikoriza untuk analisis sampel tanah menunjukkan bahwa mempertahankan keberadaannya di alam sampel tanah ketiga $\left(\mathrm{L}_{3}\right)$ mempunyai (Delvian, 2006).

kandungan $\mathrm{P}$ tersedia yang termasuk kategori

Persentase infeksi endomikoriza pada sedang (Tabel 1). Nurhandayani et al. (2013) perakaran tanaman jagung setelah menyatakan bahwa jumlah spora perbanyakan menunjukkan nilai yang sama endomikoriza menurun pada tanah yang pada semua perlakuan yaitu $100 \%$ dan mempunyai kandungan $\mathrm{P}$ tinggi. 
tingkat infeksi yang terjadi tergolong sangat tinggi (Tabel 4).

Tabel 3. Interaksi Perlakuan Lokasi Pengambilan Sampel Tanah (L) dan Kadar Air Tanah (A) pada Variabel Persentase Peningkatan Jumlah Spora Endomikoriza Setelah Perbanyakan Persentase peningkatan jumlah spora endomikoriza setelah perbanyakan (\%)

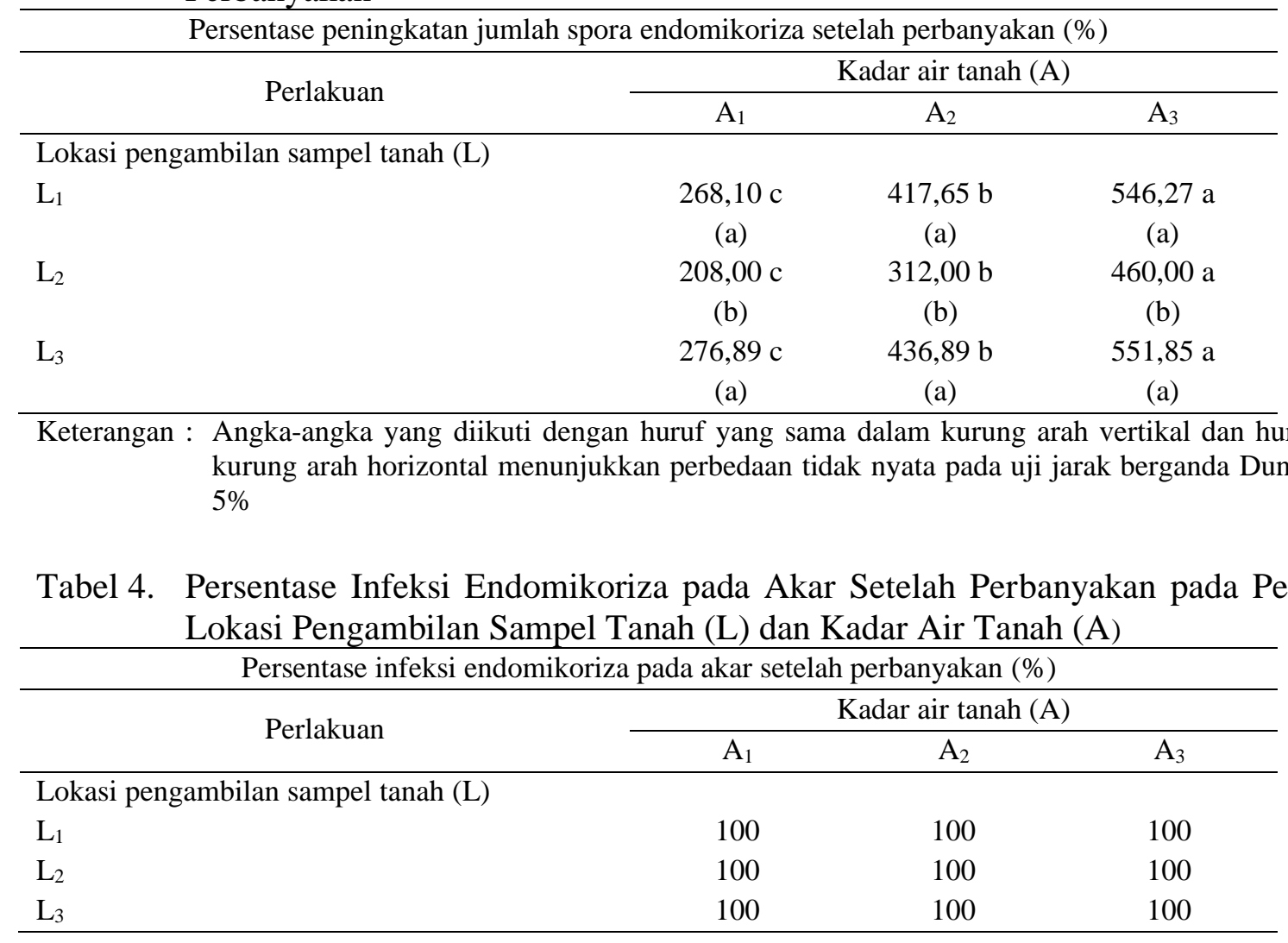

Faktor lokasi pengambilan sampel oleh mikoriza lebih dialokasikan untuk tanah (L) memberikan pengaruh yang pertumbuhan akar. berbeda tidak nyata pada variabel jumlah daun pengamatan IV, tinggi tanaman pengamatan IV, diameter batang tanaman pengamatan IV, berat basah total, dan berat kering oven total tanaman jagung (Tabel 5 dan Tabel 6). Hal ini diduga disebabkan karena penyerapan unsur hara yang dibantu
Pada variabel jumlah daun pengamatan $\mathrm{IV}$, tinggi tanaman pengamatan IV, diameter batang tanaman pengamatan IV, berat basah total, dan berat kering oven total tanaman jagung menunjukkan bahwa semakin rendah kadar air tanah maka semakin kecil nilai setiap variabelnya (Tabel 5 dan Tabel 6). 
Jumin (2012) menyatakan bahwa aktivitas

fisiologis tanaman akan terganggu apabila terjadi kekurangan air sehingga dapat mengakibatkan terhambatnya proses pertumbuhan. Manurung et al. (2015) menyatakan bahwa cekaman air pada berukuran kecil. tanaman dapat mengurangi potensial air sel tumbuhan dan turgor, yang menyebabkan menurunnya pembesaran sel dan terhambatnya pertumbuhan tanaman, sehingga bagian tanaman yang terbentuk

Tabel 5. Jumlah Daun, Tinggi Tanaman, dan Diameter Batang Tanaman (Pengamatan IV) pada Perlakuan Lokasi Pengambilan Sampel Tanah (L) dan Kadar Air Tanah (A)

\begin{tabular}{|c|c|c|c|}
\hline \multirow[b]{2}{*}{ Perlakuan } & \multicolumn{3}{|c|}{ Variabel } \\
\hline & $\begin{array}{c}\text { Jumlah daun } \\
\text { pengamatan IV (helai) }\end{array}$ & $\begin{array}{c}\text { Tinggi tanaman } \\
\text { pengamatan IV }(\mathrm{cm})\end{array}$ & $\begin{array}{c}\text { Diameter batang tanaman } \\
\text { pengamatan IV }(\mathrm{cm})\end{array}$ \\
\hline \multicolumn{4}{|c|}{ Lokasi pengambilan sampel tanah (L) } \\
\hline $\mathrm{L}_{1}$ & $10,78 \mathrm{a}$ & $17,49 \mathrm{a}$ & $0,71 \mathrm{a}$ \\
\hline $\mathrm{L}_{2}$ & $10,56 \mathrm{a}$ & $18,10 \mathrm{a}$ & $0,72 \mathrm{a}$ \\
\hline $\mathrm{L}_{3}$ & $10,56 \mathrm{a}$ & $18,27 \mathrm{a}$ & $0,71 \mathrm{a}$ \\
\hline \multicolumn{4}{|c|}{ Kadar air tanah (A) } \\
\hline $\mathrm{A}_{1}$ & $11,44 \mathrm{a}$ & $22,50 \mathrm{a}$ & $0,76 \mathrm{a}$ \\
\hline $\mathrm{A}_{2}$ & $10,44 \mathrm{~b}$ & $17,13 \mathrm{~b}$ & $0,72 \mathrm{~b}$ \\
\hline $\mathrm{A}_{3}$ & $10,00 \mathrm{~b}$ & $14,22 \mathrm{c}$ & $0,66 \mathrm{c}$ \\
\hline
\end{tabular}

Keterangan : Angka-angka yang diikuti dengan huruf yang sama pada perlakuan dan kolom yang sama menunjukkan perbedaan tidak nyata pada uji jarak berganda Duncan taraf $5 \%$

Tabel 6. Berat Basah Total dan Berat Kering Oven Total Tanaman pada Perlakuan Lokasi Pengambilan Sampel Tanah (L) dan Kadar Air Tanah (A)

\begin{tabular}{|c|c|c|}
\hline \multirow{2}{*}{ Perlakuan } & \multicolumn{2}{|c|}{ Variabel } \\
\hline & Berat basah total tanaman $(\mathrm{g})$ & Berat kering oven total tanaman $(\mathrm{g})$ \\
\hline \multicolumn{3}{|c|}{ Lokasi pengambilan sampel tanah (L) } \\
\hline $\mathrm{L}_{1}$ & $13,47 \mathrm{a}$ & $3,68 \mathrm{a}$ \\
\hline $\mathrm{L}_{2}$ & $12,68 \mathrm{a}$ & $3,50 \mathrm{a}$ \\
\hline $\mathrm{L}_{3}$ & $11,91 \mathrm{a}$ & $3,44 \mathrm{a}$ \\
\hline \multicolumn{3}{|l|}{ Kadar air tanah (A) } \\
\hline $\mathrm{A}_{1}$ & $14,72 \mathrm{a}$ & $4,12 \mathrm{a}$ \\
\hline $\mathrm{A}_{2}$ & $13,51 \mathrm{a}$ & $3,72 \mathrm{~b}$ \\
\hline $\mathrm{A}_{3}$ & $9,84 \mathrm{~b}$ & $2,78 \mathrm{c}$ \\
\hline
\end{tabular}

\begin{tabular}{ll}
\hline Keterangan $\quad \begin{array}{l}\text { Angka-angka yang diikuti dengan huruf yang sama pada perlakuan dan kolom yang sama } \\
\text { menunjukkan perbedaan tidak nyata pada uji jarak berganda Duncan taraf } 5 \%\end{array}$
\end{tabular}




\section{SIMPULAN}

1. Genus Glomus dan Acaulospora ditemukan pada lahan penanaman jagung yang sebelumnya ditanami tanaman jahe dan kedelai, sedangkan pada lahan penanaman jagung yang sebelumnya ditanami tanaman padi ditemukan genus Glomus.

2. Karakter morfologi spora endomikoriza dari genus Glomus yang ditemukan adalah mempunyai bentuk spora bulat, berwarna kuning dan cokelat, diameter spora berukuran 60-117 $\mu \mathrm{m}$, dan terdapat dudukan hifa, sedangkan karakter morfologi spora endomikoriza dari genus Acaulospora yang ditemukan adalah mempunyai bentuk spora bulat, berwarna jingga dan cokelat, diameter spora berukuran 65$103 \mu \mathrm{m}$, dan terdapat ornamen.

3. Tingkat infeksi endomikoriza pada perakaran tanaman jagung di dataran sedang tergolong sangat tinggi dengan persentase $86,67 \%$ pada lahan penanaman jagung yang sebelumnya ditanami tanaman jahe dan $83,33 \%$ pada lahan penanaman jagung yang sebelumnya ditanami tanaman padi dan kedelai.

4. Kadar air tanah yang berbeda memberikan nilai yang sama pada variabel persentase infeksi endomikoriza yaitu $100 \%$, dan tingkat infeksi yang terjadi tergolong sangat tinggi. Kadar air tanah berpengaruh sangat nyata terhadap persentase peningkatan jumlah spora endomikoriza dan penurunan kadar air tanah menyebabkan persentase peningkatan jumlah spora semakin tinggi.

\section{DAFTAR PUSTAKA}

Brundrett, M., N. Bougher, B. Dell, T. Grove, dan N. Malajczuk. 1996. Working with Mycorrhizas in Forestry and Agriculture. ACIAR Monograph 32. Australian Centre for International Agricultural Research. Canberra.

Cahyani, N. K. M. D., S. Nurhatika, dan A. Muhibuddin. 2014. Eksplorasi Mikoriza Vesikular Arbuskular (MVA) Indigenous pada Tanah Aluvial di Kabupaten Pamekasan Madura. Jurnal Sains dan Seni Pomits 3 (1): 22-25.

Chairuman, N. 2008. Efektivitas Cendawan Mikoriza Arbuskula pada Beberapa Tingkat Pemberian Kompos Jerami terhadap Ketersediaan Fosfat serta Pertumbuhan dan Produksi Padi Gogo di Tanah Ultisol. Tesis. Universitas Sumatera Utara.

Delvian. 2006. Dinamika Sporulasi Cendawan Arbuskula. Universitas Sumatera Utara.

INVAM. 2017. International Culture Collection of Vesicular and Arbuscular Mycorrhizal Fungi. Morgantown, West Virginia Agriculture and Foresty Experimental Station. http:// 
NGAKAN MADE ADI WEDAGAMA. et al. Isolasi dan Identifikasi Endomikoriza pada Perakaran...

www.invam.cat.wvu.edu (diakses tanggal 17 Januari 2018).

Jumin, H. B. 2012. Dasar-dasar Agronomi. PT RajaGrafindo Persada. Jakarta.

Manurung, Y. C., A. S. Hanafiah, dan P. Marbun. 2015. Pengaruh Berbagai Kadar Air Tanah pada Efektifitas Mikoriza Arbuskular terhadap Pertumbuhan dan Serapan Hara Bibit Karet (Hevea brassiliensis Muell. Arg.) di Rumah Kasa. Jurnal Online Agroekoteknologi 3 (2): 465-475.

Nurhandayani, R., R. Linda, dan S. Khotimah. 2013. Inventarisasi Jamur Mikoriza Vesikular Arbuskular dari Rhizosfer Tanah Gambut Tanaman Nanas (Ananas comosus (L.) Merr). Protobiont 2 (3): 146-151.

Pangaribuan, N. 2014. Penjaringan Cendawan Mikoriza Arbuskula Indigenous dari Lahan Penanaman Jagung dan Kacang Kedelai pada Gambut Kalimantan Barat. Jurnal Agro 1 (1): 50-60.

Raharja, N. C. 2015. Isolasi dan Identifikasi Fungi Mikoriza Arbuskula (FMA) Lokal pada Rhizosfer Rumput Lahan Pasca Tambang Timah di Kabupaten Belitung Timur. Skripsi. Institut Pertanian Bogor.

Suamba, I W., I G. P. Wirawan, dan W. Adiartayasa. 2014. Isolasi dan Identifikasi Fungi Mikoriza Arbuskular (FMA) secara Mikroskopis pada Rhizosfer Tanaman Jeruk (Citrus sp.) di Desa Kerta, Kecamatan Payangan, Kabupaten Gianyar. E- Jurnal Agroekoteknologi Tropika 3 (4): 201208.

Sundari, S., T. Nurhidayati, dan I. Trisnawati. 2011. Isolasi dan Identifikasi Mikoriza Indigenous dari
Perakaran Tembakau Sawah

(Nicotiana tabacum L.) di Area

Persawahan Kabupaten Pamekasan Madura. Paper. Institut Teknologi Sepuluh Nopember.

Supartha, I. N. Y., G. Wijana, dan G. M. Adnyana. 2012. Aplikasi Jenis Pupuk Organik pada Tanaman Padi Pertanian Organik. E-Jurnal Agroekoteknologi Tropika 1 (2): 98-106.

Wirawan, I W. E. A., I. K. Suada, dan I G. K. Susrama. 2015. Identifikasi Mikoriza Vesikular Arbuskular (MVA) dari Rhizosfer Tanaman Cabai (Capsicum annuum L.) dan Tomat (Solanum lycopersicum L.) serta Perbanyakannya Menggunakan Media Zeolit. E-Jurnal Agroekoteknologi Tropika 4 (4): 304313. 